\title{
Left ventricular function in chronic renal failure
}

\author{
B. S. Lewis, F. J. Milne, and B. Goldberg \\ From the fohannesburg Hospital and University of the Witwatersrand, fohannesburg, South Africa
}

Left ventricular function was studied in 14 patients with end-stage chronic renal failure using non-invasive methods (echocardiography and systolic time intervals). Patients were divided into 3 groups. Group 1 consisted of 5 patients who were normotensive at the time of study and group 2 of 7 patients who were hypertensive when studied. Group 3 consisted of 2 patients: one was receiving propranolol and the other, studied 302 days after renal transplantation, was receiving digitalis for recurrent episodes of cardiac failure.

All except the patient receiving propranolol had normal left ventricular function in systole with normal measurements of fractional fibre shortening $(\% \Delta S, E F)$ and normal measurements relating to the velocity of ventricular contraction (mean Vcf, mean velocity of posterior wall motion). Stroke volume and cardiac output were normal in some patients but were increased in patients with fluid overload. Early diastolic compliance of the left ventricle seemed to be normal except in the patient with recurrent cardiac failure. The study provided no evidence for the existence of a specific uraemic cardiomyopathy.

Cardiac failure is common in patients with chronic renal failure, but its mechanism is uncertain. The existence of a specific uraemic cardiomyopathy has been suggested, but there are no detailed studies of left ventricular function in patients with chronic renal disease (Agrest and Finkielman, 1967; Del Greco et al., 1969; Gueron et al., 1975; Prosser and Parsons, 1975).

Non-invasive techniques are now widely used in the assessment of cardiac performance (Weissler, 1974). The data obtained correlate well with measurements made at cardiac catheterization, and the non-invasive methods have the advantage that they can be made and repeated at the bedside without distressing or harming the patient. Noninvasive techniques include the recording and measurement of the time intervals of the cardiac cycle (Weissler, Peeler, and Roehll, 1961; Weissler, Harris, and Schoenfeld, 1968; Kumar and Spodick, 1970; Lewis et al., 1973) and echocardiography (Feigenbaum, 1972; Fortuin, Hood, and Craige, 1972; McDonald, 1974). We have used the systolic time intervals and echocardiography to study myocardial performance in detail in a group of patients with chronic renal failure.

\section{Patients}

Fourteen patients with chronic renal failure were studied. The clinical data are given in Table 1. The Received 3 February 1976. patients were divided into 3 groups: 5 patients were normotensive at the time of study (group 1) $(B P \leqslant 140 / 90 \mathrm{mmHg})$. Two of these had been hypertensive and the blood pressure reduced effectively with treatment. Seven patients were hypertensive (group 2) (BP $\geqslant 150 / 100 \mathrm{mmHg}$ ). Two patients were classified separately (group 3 ): 1 patient (Case 13) was studied 302 days after renal transplantation; he had had recurrent episodes of cardiac failure and was receiving digitalis. The other patient (Case 14) had been hypertensive, but was being treated with a beta-adrenergic blocking drug (propranolol) at the time of study. Several patients were receiving other drugs: these are shown in Table 1.

One patient in group 1 (Case 3 ) and 3 patients in group 2 (Cases 10,11, and 12) were very ill at the time of study because of severe fluid overload and were dialysed peritoneally immediately after the cardiac measurements were made. The data from these patients were compared with those of patients not in frank cardiac failure.

All patients were anaemic and had raised serum urea and creatinine levels: there was no difference in these measurements between groups 1 and 2 (unpaired t-test). One patient in group 1 (Case 3) was an elderly man who had chronic obstructive airways disease and one in group 2 (Case 9) had overt coronary artery disease with an ischaemic resting electrocardiogram. The patient studied after renal transplantation had an arteriovenous 
TABLE 1 Clinical and biochemical data

\begin{tabular}{|c|c|c|c|c|c|c|c|c|c|c|c|c|}
\hline Case No. & Age & Sex & Diagnosis & $\begin{array}{l}\text { Pulse } \\
\text { (beatsimin) }\end{array}$ & $\begin{array}{l}\text { Arterial } B P \\
S / D\end{array}$ & $\begin{array}{c}P(m m H g) \\
(\text { mean })\end{array}$ & $\begin{array}{l}\mathcal{F V P} \\
(\mathrm{cm})\end{array}$ & Oedema & Apex beat & $S_{3}$ & $S_{4}$ & $H b(g / d l)$ \\
\hline \multicolumn{13}{|c|}{ Group $1:$ normotensive patients } \\
\hline 1 & 57 & $\mathbf{F}$ & AN & 80 & $130 / 80$ & (97) & 0 & 0 & $\mathrm{LV}++$ & - & + & $8 \cdot 0$ \\
\hline 2 & 46 & $\mathbf{F}$ & AN & 86 & $140 / 80$ & (100) & 0 & 0 & $\mathrm{LV}+$ & - & + & $8 \cdot 6$ \\
\hline 3 & 66 & $\mathrm{M}$ & Amyloidosis + COPD & 90 & $130 / 90$ & (103) & +2 & + & Not palpable & - & - & $5 \cdot 8$ \\
\hline 4 & 54 & $\mathbf{F}$ & Chronic renal failure & 70 & $140 / 80$ & $(100)$ & 0 & 0 & Normal & - & - & $9 \cdot 9$ \\
\hline 5 & 29 & $\mathbf{F}$ & CPN & 80 & $140 / 80$ & $(100)$ & 0 & 0 & Normal & - & - & $7 \cdot 5$ \\
\hline \multicolumn{4}{|c|}{ Mean \pm SD $50 \pm 14$} & $81 \pm 8$ & & $(100 \pm 2)$ & & & & & & $8 \cdot 0 \pm 1 \cdot 5$ \\
\hline
\end{tabular}

Group 2: hypertensive patients

\begin{tabular}{|c|c|c|c|c|c|c|c|c|c|c|c|c|}
\hline $\begin{array}{l}6 \\
7 \\
8\end{array}$ & $\begin{array}{l}29 \\
40 \\
43\end{array}$ & $\begin{array}{l}\text { M } \\
\text { M } \\
\text { F }\end{array}$ & $\begin{array}{l}\text { CGN } \\
\text { AN } \\
\text { SLE }\end{array}$ & $\begin{array}{l}70 \\
75 \\
75\end{array}$ & $\begin{array}{l}190 / 112 \\
160 / 106 \\
170 / 100\end{array}$ & $\begin{array}{l}(138) \\
(124) \\
(123)\end{array}$ & $\begin{array}{l}0 \\
0 \\
0\end{array}$ & $\begin{array}{l}0 \\
0 \\
+\end{array}$ & $\begin{array}{l}\text { LV+ } \\
\text { LV+ } \\
\text { LV+ }\end{array}$ & $\begin{array}{l}- \\
-\end{array}$ & $\begin{array}{l}\overline{+} \\
+\end{array}$ & $\begin{array}{r}10 \cdot 5 \\
10 \cdot 0 \\
7 \cdot 4\end{array}$ \\
\hline $\begin{array}{r}9 \\
10 \\
11\end{array}$ & $\begin{array}{l}57 \\
29 \\
43\end{array}$ & $\begin{array}{l}\mathbf{M} \\
\mathbf{M} \\
\mathbf{M}\end{array}$ & $\begin{array}{l}\text { CGN+CAD } \\
\text { MGN } \\
\text { CGN }\end{array}$ & $\begin{array}{r}100 \\
75 \\
100\end{array}$ & $\begin{array}{l}150 / 100 \\
180 / 130 \\
190 / 120\end{array}$ & $\begin{array}{l}(117) \\
(147) \\
(143)\end{array}$ & $\begin{array}{l}+5 \\
+3 \\
+5\end{array}$ & $\begin{array}{l}0 \\
0 \\
0\end{array}$ & $\begin{array}{l}\mathrm{LV}+ \\
\mathrm{LV}++ \\
\mathrm{LV}++\end{array}$ & $\begin{array}{l}+ \\
- \\
-\end{array}$ & $\begin{array}{l}\dot{+} \\
+\end{array}$ & $\begin{array}{r}6 \cdot 9 \\
5 \cdot 2 \\
10 \cdot 3\end{array}$ \\
\hline 12 & 48 & $\mathbf{M}$ & AN & 100 & $200 / 110$ & $(140)$ & +4 & 0 & $\mathrm{LV}++$ & - & + & $7 \cdot 9$ \\
\hline
\end{tabular}

Group 3: miscellaneous

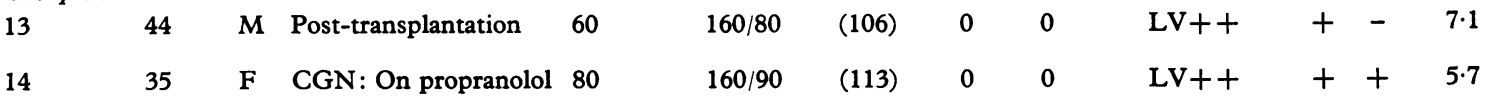

$\mathrm{AN}$, analgesic nephropathy; CAD, coronary artery disease; CGN, chronic glomerulonephritis; COPD, chronic obstructive airways disease; CPN, chronic pyelonephritis; MGN, membranous glomerulonephritis; SLE, systemic lupus erythematosus.

Conversion from SI Units to Traditional Units: Urea: $1 \mathrm{mmol} / 1 \approx 6.024 \mathrm{mg} / 100 \mathrm{ml}$; creatinine: $1 \mathrm{mmol} / 1 \approx 0.0113 \mathrm{mg} / 100 \mathrm{ml}$.

shunt at the time of study. Fistulae or shunts were not present in the other patients.

\section{Methods}

Patients were studied in a comfortable semirecumbent position. The systolic and diastolic time intervals of the cardiac cycle were measured from simultaneous electrocardiogram (ECG), phonocardiogram (PCG), and carotid pulse tracing or apex cardiogram (ACG), using a Cambridge multichannel photographic recorder and a paper speed of $100 \mathrm{~mm} / \mathrm{s}$. The apex cardiogram was recorded with the patient in the left lateral position since this provides high quality recordings for measurement. An air-filled funnel transducer was used for the carotid and apex recordings.

Measurement of the systolic time intervals was followed immediately in 9 patients by echocardiography, using an Ekoline 20 machine (Smith-Kline Instruments). A C-12 $2 \cdot 25 \mathrm{MHz}$ focused transducer was used. The transducer was placed in the 3 rd to 5 th interspace near the left sternal border and care- fully directed to obtain, successively, echozardiographic recordings of the mitral valve, aortic rootleft atrium, and the left ventricle according to standard techniques (Feigenbaum, 1972; Popp et al., 1975). A permanent record of the echocardiograms was made with a polaroid camera.

Serial studies of left ventricular function were made on Case 12. Measurements were made immediately before dialysis and repeated 3 hours after a 40-hour peritoneal dialysis during which the patient lost $4 \mathrm{~kg}$ in weight.

\section{Data analysis}

\section{(1) Time interval measurements}

(a) Systolic measurements (Fig. 1) Preejection period (PEP) is the time from the first deflection of the QRS complex on the electrocardiogram to the onset of the rapid upstroke of the carotid pulse tracing, which corresponds to aortic valve opening. PEP must be corrected for pulse transmission time delay; this was done by comparing the timing of the dicrotic notch of the carotid 


\begin{tabular}{llll}
\hline $\begin{array}{l}\text { Urea } \\
(\text { momol } / l)\end{array}$ & $\begin{array}{l}\text { Creatinine } \\
(m m s o l / l)\end{array}$ & $\begin{array}{l}K+ \\
(m m o l / l)\end{array}$ & Drugs \\
\hline & & & \\
18 & 902 & 4.6 & Methyldopa, frusemide \\
20 & 557 & $5 \cdot 2$ & Methyldopa, frusemide \\
35 & 1353 & $6 \cdot 3$ & Nil \\
36 & 1185 & $4 \cdot 1$ & Chlorthalidone \\
41 & 1291 & $5 \cdot 1$ & Nil \\
\hline $30 \pm 10$ & $1061 \pm 327$ & $5 \cdot 1 \pm 0.8$ & \\
\hline
\end{tabular}

\begin{tabular}{|c|c|c|c|}
\hline $\begin{array}{l}22 \\
25 \\
29\end{array}$ & $\begin{array}{l}831 \\
690 \\
318\end{array}$ & $\begin{array}{l}5.0 \\
4 \cdot 4 \\
3.5\end{array}$ & $\begin{array}{l}\text { Methyldopa, chlorothiazide } \\
\text { Methyldopa } \\
\text { Methyldopa, bethanidine, }\end{array}$ \\
\hline $\begin{array}{l}32 \\
40 \\
37\end{array}$ & $\begin{array}{l}1105 \\
1777 \\
1025\end{array}$ & $\begin{array}{l}5 \cdot 7 \\
5 \cdot 4 \\
4 \cdot 5\end{array}$ & $\begin{array}{l}\text { Frusemide } \\
\text { Nil } \\
\text { Methyldopa; hydrallazine, } \\
\text { frusemide }\end{array}$ \\
\hline 49 & 2122 & $5 \cdot 0$ & $\mathrm{Nil}$ \\
\hline $34 \pm 9$ & $1123 \pm 628$ & $4 \cdot 8 \pm 0 \cdot 7$ & \\
\hline 19 & 292 & 3.5 & $\begin{array}{l}\text { Digoxin, frusemide, clonidine, } \\
\text { azathioprine, prednisolone }\end{array}$ \\
\hline 35 & 1512 & $5 \cdot 8$ & Propranolol (20 mg tds) \\
\hline
\end{tabular}

pulse tracing with the aortic component of the second heart sound (A2). PEP has 3 components: the electromechanical interval (which cannot be measured), the time from mechanical activation to the time of left ventricular pressure rise, and the isovolumic contraction time (ICT). ICT may be calculated from apex cardiogram (ICT ACG $_{\text {) or }}$ from phonocardiogram (ICT $\mathrm{PCG}$ ), thus:

$$
\mathrm{ICT}_{\mathrm{ACG}}=\mathrm{PEP}-\left(\mathrm{Q}-\mathrm{U}_{\mathrm{ACG}}\right)
$$

where $Q-U_{A C G}=$ time from $Q R S$ onset to the upstroke of apex cardiogram (ACG)

and $\quad$ ICT $_{\text {PCG }}=$ PEP-(Q-M1)

where $Q-M 1$ is the time interval from QRS onset to the first high frequency component of the first heart sound.

We used ICT $T_{A C G}$ since it is more accurate: $U_{A C G}$ corresponds to the onset of $\mathrm{LV}$ pressure rise and does not depend on changes in loading conditions (Kumar and Spodick, 1970). PEP and ICT are useful measurements of cardiac function and are closely related to the isovolumic velocity indices of LV function (peak LV dp/dt; $V_{\max }$ ) but are also affected by LV end-diastolic pressure and aortic diastolic pressure.

Left ventricular ejection time (LVET) is the time from aortic valve opening to aortic valve closure and is measured from the upstroke of the carotid pulse tracing to the nadir of its dicrotic notch. LVET is related to stroke volume, afterload, and heart rate; it also depends ultimately on the state of myocardial contractility.

Total electromechanical systole $\left(\mathrm{Q}-\mathrm{A}_{\mathbf{2}}\right)$ is the sum of PEP and LVET.

The STI measurements (except ICT) are ratedependent. We calculated $\triangle \mathrm{PEP}, \triangle \mathrm{Q}-\mathrm{M1}$, $\Delta \mathrm{LVET}$, and $\Delta \mathrm{Q}-\mathrm{A} 2$ where the $\Delta$ value is the dif-

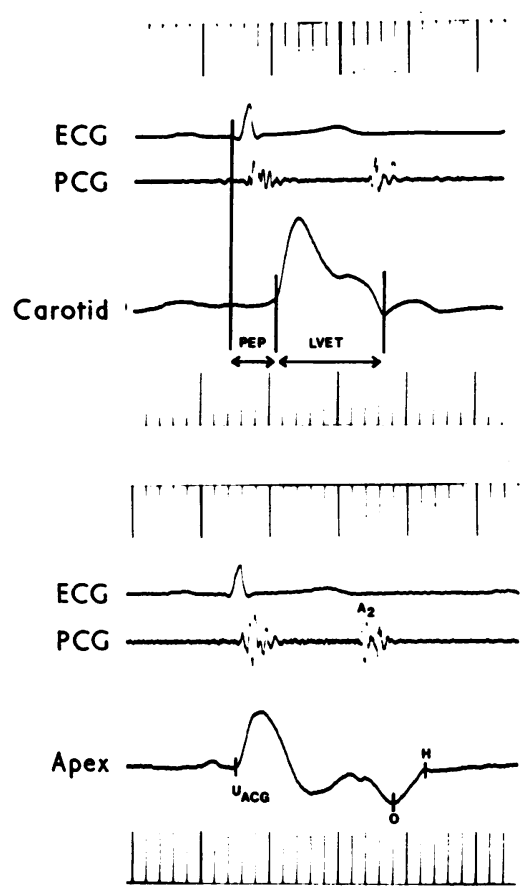

FIG. 1 Method for measuring the time intervals of the cardiac cycle. Upper panel: simultaneous recording of the electrocardiogram (ECG), phonocardiogram (PCG), and external carotid pulse tracing. Pre-ejection period (PEP) is the time from the onset of the $Q R S$ complex to the upstroke of the carotid pulse, after correction for pulse transmission time delay. Left ventricular ejection time (LVET) is measured from the carotid upstroke to its dicrotic notch. Lower panel: simultaneous recording of $E C G$, $P C G$, and apex cardiogram permits calculation of the isovolumic contraction time (PEP minus $Q-U_{\mathrm{ACG}}$ ), isovolumic relaxation period $(A 2-0)$, and rapid filling phase $(\mathrm{O}-\mathrm{H})$. 
ference between the measured value and the normal predicted value for a given heart rate (Weissler et al., 1968).

The ratio $P E P / L V E T$ was calculated. This ratio magnifies abnormalities of cardiac function and is related to ejection fraction (Garrard, Weissler, and Dodge, 1970).

(b) Diastolic measurements Isovolumic relaxation period (IRP) was measured as the time interval from A2 on the PCG to the 0 point of the apex cardiogram $^{1}$. The $\mathrm{O}-\mathrm{H}$ time is the duration of the rapid ventricular filling phase and was measured on the apex cardiogram (Fig. 1).

All systolic time interval measurements were made by a single experienced observer and the mean values over several cardiac cycles were used. Measurements were corrected to the nearest $5 \mathrm{~ms}$. The apex cardiogram was difficult to record in patients with a large chest wall or in those who were distressed: for this reason ICT, IRP, and the $\mathrm{O}-\mathrm{H}$ time were not calculated in all patients.

\section{(2) Echocardiographic measurements}

(a) Length and volume measurements The diameter of the left ventricle in its minor axis was measured at end-diastole (Dd) and at endsystole (Ds). Percentage dimension change $(\% \Delta s)$ was calculated:

$$
\% \Delta \mathrm{S}=\frac{\mathrm{Dd}-\mathrm{Ds}}{\mathrm{Dd}} \times 100 \%
$$

Left ventricular volumes were derived from the cube of the single-plane diameter measurements (Feigenbaum, 1972; McDonald, 1974). Enddiastolic (EDV) and end-systolic volume (ESV) were calculated and stroke volume (SV) and ejection fraction (EF) were derived. Ejection fraction (EF) is the volume equivalent of the linear measurement $(\% \Delta S)$.

$$
\begin{aligned}
& \mathrm{EF}=\frac{\mathrm{EDV}-\mathrm{ESV}}{\mathrm{EDV}} \times 100 \% \\
& \text { Cardiac output }(\mathrm{CO}) \text { was obtained from the } \\
& \text { formula } \\
& \mathrm{CO}(\mathrm{l} / \mathrm{min})=\mathrm{SV}(\mathrm{ml}) \times \text { heart rate (beats } / \mathrm{min}) \text {. }
\end{aligned}
$$

\footnotetext{
1 The time interval A2-0 point is an approximation of the isovolumic relaxation period, since the mitral valve opens and significant ventricular filling occurs before the 0 point (Prewitt et al., 1975). This time interval is better called 'ventricular relaxation period' though we have retained the term 'isovolumic' for uniformity with other published studies. The 0 point of the apex cardiogram corresponds very closely to the 0 point of the left ventricular pressure pulse, the nadir of the ventricular pressure pulse tracing in early diastole (Manolas et al., 1975).
}

(b) Velocity measurements of left ventricular function Velocity measurements were derived from a combination of echocardiographic and time interval data. The mean velocity of circumferential fibre shortening (mean Vcf) is considered a good ejection phase index of ventricular performance (Karliner et al., 1971; Skloven et al., 1972; Ross, Covell, and Mahler, 1974; Quinones et al., 1975).

$$
\text { Mean Vcf }=\frac{\text { Dd-Ds }}{\text { Dd } \times \text { LVET }}(\operatorname{circ} / \mathrm{s})
$$

We also measured the velocity of posterior $\mathrm{LV}$ wall motion (Vpwm), using the formula:

$$
\begin{aligned}
& \text { Mean Vpwm } \\
& =\frac{\text { Total pwm during ejection }(\mathrm{mm} / \mathrm{s})}{\text { LVET }}
\end{aligned}
$$

(c) Diastolic function of the left ventricle The diastolic closure rate of the anterior mitral leaflet (mitral DCR; EF slope) was measured from 3 to 5 complexes showing maximal amplitude of anterior mitral leaflet excursion; the EF slope was essentially monophasic in all the echocardiograms. In the absence of mitral valve disease the EF slope is related to stroke volume and left ventricular pressure-volume relations (Quinones et al., 1974).

\section{Critique of methods}

Echocardiographic data These are now widely used in studies of left ventricular function but must be analysed critically (Linhart et al., 1975). The single-plane echocardiogram measures a single diameter of the left ventricle. Calculations of ventricular volume assume a constant relation between this diameter and the volume of the left ventricle: this assumption may not be valid in patients with hypertrophied, volume-overloaded, or irregularly shaped ventricles. Absolute measurements of left ventricular volumes and cardiac output may, therefore, be inaccurate, but this criticism does not apply to the diameter measurements themselves, to the velocity measurement Vcf, and to measurements of fractional fibre shortening ( $\% \Delta S$; EF). We used polaroid echocardiographic recordings: small errors in measurement are magnified when the diameter and volume measurements are computed. For these reasons echocardiographic measurements of left ventricular function were made in only 8 patients, from whom high quality recordings were obtained.

Statistical analysis of differences in the results between groups was not performed since the number of patients in each group was small: Normal values for STI and echocardiographic 
measurements are taken from large series of published reports (Weissler et al., 1968; Kumar and Spodick, 1970; McDonald et al., 1972).

\section{Results}

The results are summarized in Tables 2 to 4 .

\section{Time interval measurements (Table 2)}

PEP and $\triangle$ PEP were normal in most patients in group 1 and increased in some patients in group 2 $(p>0.05)$. The increase in $\triangle$ PEP seemed to be related to a high arterial diastolic pressure (Fig. 2). An increase in $\triangle P E P$, however, was also related to an increase in $\Delta \mathrm{Q}-\mathrm{M} 1(\mathrm{r}=0.77, \mathrm{P}<0.01)$ (Fig. 3), indicating that in some patients $\triangle \mathrm{PEP}$ may have been increased by a greater preload. ICTACG was normal or decreased and this finding suggests an increased velocity of ventricular contraction. This implies that myocardial contractility was good in spite of abnormal loading conditions sufficient to affect $\triangle \mathrm{PEP}$ and $\triangle \mathrm{Q}-\mathrm{M} 1$.

LVET and $\triangle$ LVET were normal in most patients. $\triangle$ LVET was slightly longer in 2 patients in group 2 (hypertensive patients). LVET and $\triangle$ LVET were decreased in Case 14, who was taking propranolol, and in Case 4, in whom all systolic time interval measurements were decreased and for which no apparent explanation was present.

The ratio $P E P / L V E T$ reflected the changes in PEP and LVET and was increased in patients in group 2 who had a prolonged PEP. It was also increased in the older patient with chest disease (Case 3 in group 1). PEP/LVET was not related to ejection fraction, as calculated from the echocardiogram. Total electromechanical systole $\left(\mathrm{Q}-\mathrm{A}_{2}\right)$ was normal in most patients, though perhaps slightly

TABLE 2 Time interval measurements

\begin{tabular}{|c|c|c|c|c|c|c|c|c|c|c|c|c|c|}
\hline $\begin{array}{l}\text { Case } \\
\text { No. }\end{array}$ & $\begin{array}{l}H R \\
\text { (beats } \\
\text { (min) }\end{array}$ & $\begin{array}{l}P E P \\
(m s)\end{array}$ & $\begin{array}{l}\triangle P E P \\
(m s)\end{array}$ & $\begin{array}{l}\text { LVET } \\
(m s)\end{array}$ & $\begin{array}{l}\Delta L V E T \\
(m s)\end{array}$ & $\begin{array}{l}P E P / \\
L V E T\end{array}$ & $\begin{array}{l}I C T_{A C G} \\
(\mathrm{~ms})\end{array}$ & $\begin{array}{l}Q-M 1 \\
(m s)\end{array}$ & $\begin{array}{l}\Delta Q-M 1 \\
(m s)\end{array}$ & $\begin{array}{l}I R P \\
(m s)\end{array}$ & $\begin{array}{l}O-H \\
(m s)\end{array}$ & $\begin{array}{l}Q-A 2 \\
(m s)\end{array}$ & $\begin{array}{l}\Delta Q-A 2 \\
(m s)\end{array}$ \\
\hline \multicolumn{14}{|c|}{ Group 1 : normotensive patients } \\
\hline $\begin{array}{l}1 \\
2 \\
3 \\
4 \\
5\end{array}$ & $\begin{array}{l}92 \\
80 \\
87 \\
60 \\
88\end{array}$ & $\begin{array}{r}95 \\
115 \\
120 \\
95 \\
105\end{array}$ & $\begin{array}{c}-1 \\
+14 \\
+24 \\
-14 \\
+7\end{array}$ & $\begin{array}{l}265 \\
300 \\
250 \\
290 \\
265\end{array}$ & $\begin{array}{l}-6 \\
+10 \\
-15 \\
-32 \\
-12\end{array}$ & $\begin{array}{l}0.36 \\
0.38 \\
0 \cdot 48 \\
0.33 \\
0.40\end{array}$ & $\begin{array}{l}55 \\
- \\
45 \\
70\end{array}$ & $\begin{array}{c}70 \\
55 \\
- \\
45 \\
60\end{array}$ & $\begin{array}{l}+9 \\
-10 \\
- \\
-26 \\
-3\end{array}$ & $\frac{85}{-}$ & $\begin{array}{l}- \\
\overline{110}\end{array}$ & $\begin{array}{l}360 \\
415 \\
370 \\
385 \\
370\end{array}$ & $\begin{array}{l}-5 \\
+26 \\
+7 \\
-44 \\
-3\end{array}$ \\
\hline $\begin{array}{l}\text { Mean } \\
\pm S D\end{array}$ & $81 \pm 13$ & $\begin{array}{l}106 \\
\pm 11\end{array}$ & $\begin{array}{l}+6 \\
\pm 14\end{array}$ & $274 \pm 20$ & $\begin{array}{l}-11 \\
\pm 15\end{array}$ & $\begin{array}{l}0.39 \\
\pm 0.06\end{array}$ & $57 \pm 13$ & $\begin{array}{l}58 \\
\pm 10\end{array}$ & $-8 \pm 15$ & 83 & 110 & $380 \pm 22$ & $-4 \pm 26$ \\
\hline \multicolumn{14}{|c|}{ Group $2:$ hypertensive patients } \\
\hline $\begin{array}{r}6 \\
7 \\
8 \\
9 \\
10 \\
11 \\
12\end{array}$ & $\begin{array}{l}67 \\
82 \\
75 \\
89 \\
73 \\
97 \\
98\end{array}$ & $\begin{array}{r}120 \\
100 \\
110 \\
127 \\
130 \\
125 \\
80\end{array}$ & $\begin{array}{l}+16 \\
+2 \\
+7 \\
+32 \\
+28 \\
+33 \\
-12\end{array}$ & $\begin{array}{l}280 \\
290 \\
307 \\
240 \\
305 \\
240 \\
245\end{array}$ & $\begin{array}{c}-19 \\
+16 \\
+9 \\
-22 \\
+16 \\
-8 \\
-1\end{array}$ & $\begin{array}{l}0.43 \\
0.34 \\
0.36 \\
0.53 \\
0.43 \\
0.52 \\
0.32\end{array}$ & $\begin{array}{l}50 \\
40 \\
55 \\
\frac{75}{50}\end{array}$ & $\begin{array}{l}60 \\
55 \\
60 \\
75 \\
80 \\
75 \\
35\end{array}$ & $\begin{array}{l}-3 \\
-2 \\
-6 \\
+21 \\
+19 \\
+24 \\
-16\end{array}$ & $\begin{array}{c}95 \\
65 \\
130 \\
\overrightarrow{130} \\
-80\end{array}$ & $\begin{array}{r}140 \\
140 \\
70 \\
-95 \\
-80\end{array}$ & $\begin{array}{l}400 \\
390 \\
417 \\
367 \\
435 \\
365 \\
325\end{array}$ & $\begin{array}{l}-5 \\
+16 \\
+18 \\
+8 \\
+61 \\
+23 \\
-25\end{array}$ \\
\hline $\begin{array}{l}\text { Mean } \\
\pm S D\end{array}$ & $83 \pm 12$ & $\begin{array}{l}113 \\
\pm 18\end{array}$ & $\begin{array}{l}+15 \\
\pm 17\end{array}$ & $272 \pm 30$ & $-1 \pm 15$ & $\begin{array}{l}0.42 \\
\pm 0.08\end{array}$ & $54 \pm 13$ & $\begin{array}{l}63 \\
\pm 16\end{array}$ & $+5 \pm 16$ & $100 \pm 29$ & $105 \pm 33$ & $386 \pm 37$ & $+14 \pm 27$ \\
\hline \multicolumn{14}{|c|}{ Group 3: miscellaneous } \\
\hline $\begin{array}{l}13 \\
14\end{array}$ & $\begin{array}{l}60 \\
63\end{array}$ & $\begin{array}{l}125 \\
110\end{array}$ & $\begin{array}{l}+18 \\
+2\end{array}$ & $\begin{array}{l}310 \\
275\end{array}$ & $\begin{array}{l}-1 \\
-42\end{array}$ & $\begin{array}{l}0 \cdot 40 \\
0.40\end{array}$ & $\begin{array}{l}25 \\
75\end{array}$ & $\begin{array}{r}105 \\
50\end{array}$ & $\begin{array}{r}+39 \\
-20\end{array}$ & $\stackrel{45}{-}^{4}$ & - & $\begin{array}{l}435 \\
385\end{array}$ & $\begin{array}{l}+15 \\
-38\end{array}$ \\
\hline $\begin{array}{l}\text { Norma } \\
\text { value* } \\
\pm S D\end{array}$ & & & $\begin{array}{r}0 \pm 11 \\
(F) \\
0 \pm 13 \\
(M)\end{array}$ & & $0 \pm 10$ & $\begin{array}{r}0.35 \pm \\
0.04\end{array}$ & $70 \pm 16$ & & $\begin{array}{r}0 \pm 09 \\
(F) \\
0 \pm 11 \\
(M)\end{array}$ & $67 \pm 14$ & $\begin{array}{r}99 \cdot 8= \\
14 \cdot 2\end{array}$ & & $0 \pm 14$ \\
\hline
\end{tabular}

See text for details of abbreviations and indices; $F$, female; $M$, male.

$\star$ Weissler, Harris, and Schoenfeld (1968); Kumar and Spodick (1970). 
TABLE 3 Echocardiographic data

\begin{tabular}{|c|c|c|c|c|c|c|c|c|c|c|c|}
\hline $\begin{array}{l}\text { Case } \\
\text { No. }\end{array}$ & $\begin{array}{l}D d \\
(\mathrm{~cm})\end{array}$ & $\begin{array}{l}D s \\
(\mathrm{~cm})\end{array}$ & $\% \Delta S$ & $\begin{array}{l}E D V \\
(m l)\end{array}$ & $\begin{array}{l}E S V \\
(m l)\end{array}$ & $\begin{array}{l}S V \\
(m l)\end{array}$ & $\begin{array}{l}E F \\
(\%)\end{array}$ & $\begin{array}{l}C O \\
(l / \min )\end{array}$ & $\begin{array}{l}\text { Mean Vpwm } \\
(\mathrm{mm} / \mathrm{s})\end{array}$ & $\begin{array}{l}\text { Mean } V c f \\
(\text { circ/s) }\end{array}$ & $\begin{array}{l}\text { Mitral } D C R \\
(\mathrm{~mm} / \mathrm{s})\end{array}$ \\
\hline \multicolumn{12}{|c|}{ Group 1 : normotensive patients } \\
\hline 1 & - & - & 一 & - & - & - & - & - & - & - & - \\
\hline 2 & 4.8 & $3 \cdot 2$ & 34 & 112 & 32 & 80 & 71 & $6 \cdot 4$ & $39 \cdot 3$ & $1 \cdot 13$ & 56 \\
\hline 3 & $6 \cdot 5$ & $4 \cdot 8$ & 27 & 275 & 107 & 168 & 61 & $14 \cdot 9$ & - & 1.08 & 160 \\
\hline 4 & - & 一 & - & - & - & - & - & - & $37 \cdot 6$ & - & - \\
\hline 5 & $4 \cdot 7$ & $3 \cdot 3$ & 31 & 106 & 35 & 71 & 67 & $6 \cdot 2$ & $41 \cdot 1$ & $1 \cdot 17$ & 80 \\
\hline \multicolumn{12}{|c|}{ Group 2: hypertensive patients } \\
\hline 6 & $4 \cdot 4$ & $2 \cdot 7$ & 39 & 85 & 20 & 65 & 76 & $4 \cdot 4$ & $39 \cdot 3$ & 1.38 & 61 \\
\hline 7 & - & - & - & - & - & - & - & - & - & - & 78 \\
\hline 8 & - & - & - & - & - & - & - & 一 & - & 一 & - \\
\hline 9 & - & - & - & - & - & 一 & - & - & - & 一 & 121 \\
\hline 10 & $5 \cdot 0$ & 3.4 & 32 & 125 & 39 & 86 & 69 & $6 \cdot 3$ & $36 \cdot 1$ & 1.05 & 80 \\
\hline 11 & - & - & 一 & - & - & - & - & - & - & - & - \\
\hline 12 & $5 \cdot 8$ & $3 \cdot 8$ & 35 & 195 & 55 & 140 & 72 & $14 \cdot 7$ & $68 \cdot 2$ & $1 \cdot 41$ & 130 \\
\hline \multicolumn{12}{|c|}{ Group 3: miscellaneous } \\
\hline $\begin{array}{l}13 \\
14\end{array}$ & $\begin{array}{l}6 \cdot 6 \\
6 \cdot 2\end{array}$ & $\begin{array}{l}4.0 \\
4.9\end{array}$ & $\begin{array}{l}39 \\
21\end{array}$ & $\begin{array}{l}287 \\
238\end{array}$ & $\begin{array}{r}64 \\
118\end{array}$ & $\begin{array}{l}223 \\
120\end{array}$ & $\begin{array}{l}78 \\
50\end{array}$ & $\begin{array}{r}13 \cdot 4 \\
7 \cdot 6\end{array}$ & $\begin{array}{l}51 \cdot 6 \\
24 \cdot 4\end{array}$ & $\begin{array}{l}1.27 \\
0.76\end{array}$ & $\begin{array}{l}97 \\
-\end{array}$ \\
\hline $\begin{array}{l}\text { Normal } \\
\text { value } \\
\pm S D\end{array}$ & $\begin{array}{l}4 \cdot 4 \\
\pm 0 \cdot 28\end{array}$ & $\begin{array}{l}2 \cdot 83 \\
\pm 0 \cdot 26\end{array}$ & $\begin{array}{l}35 \cdot 5 \\
\pm 3.9\end{array}$ & $86 \pm 16$ & $23 \pm 6$ & $63 \pm 12$ & $73 \pm 5$ & $4 \cdot 3 \pm 0$ & & $1 \cdot 22 \pm 0 \cdot 13$ & $3-$ \\
\hline
\end{tabular}

See text for details of abbreviations and indices.

$\star$ McDonald, Feigenbaum, and Chang (1972).

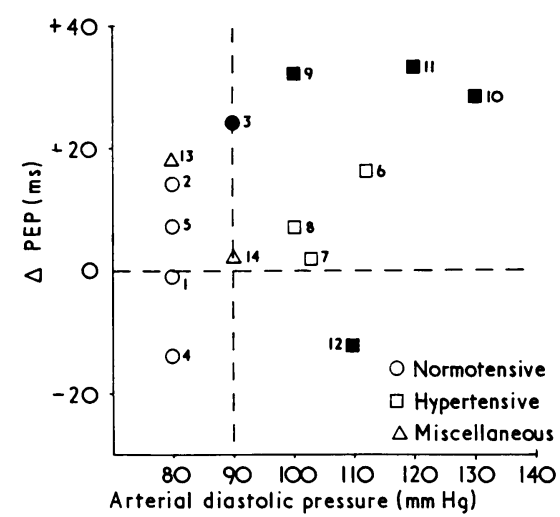

FIG. 2 Relation between arterial diastolic pressure and $\triangle P E P$. The patients' numbers correspond to those in Table 1 and the solid symbols indicate patients in whom the jugular venous pressure ( $\mathcal{F} V P)$ was increased. PEP is increased in patients with an increased arterial blood pressure. Patients with fluid overload and an increased jugular venous pressure have the highest diastolic pressures and the greatest $\triangle P E P$.

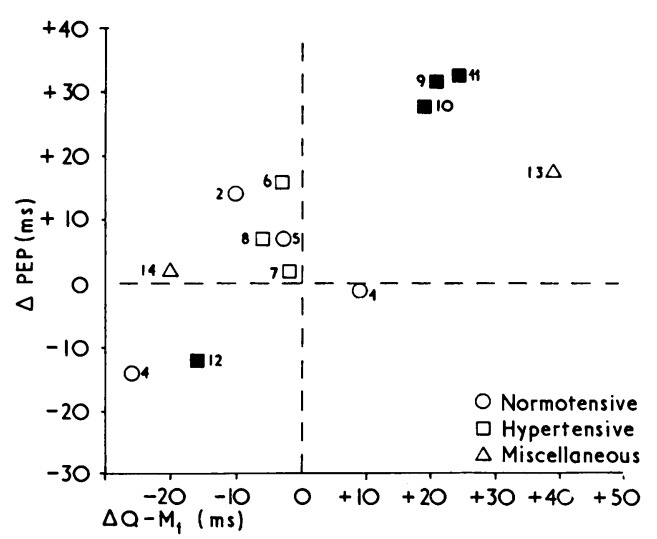

FIG. 3 Linear relation between $\Delta Q-M 1$ and $\triangle P E P(r=0.77, P<0.01)$. Case 13 has a great increase in $Q-M 1$ : he did not have an increase in arterial diastolic pressure to account for the prolonged PEP. 
prolonged in the hypertensive group. This finding is in agreement with previous studies in hypertensive patients (Shah and Slodki, 1964).

IRP was normal or increased and the increase was greater in some hypertensive patients. IRP was related to ICT $(r=0.73, P<0.05)$. The $\mathrm{O}-\mathrm{H}$ time (rapid filling period) was normal in most patients but the range was large ( 70 to $140 \mathrm{~ms}$ ).

\section{Echocardiographic studies}

The left ventricle was enlarged, especially in patients who had overt volume overload and cardiac

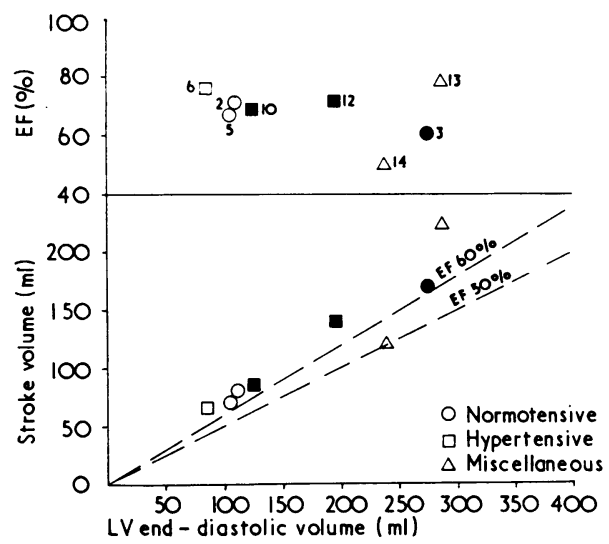

FIG. 4 Relation between end-diastolic volume (EDV) and stroke volume (SV). Isopleths of ejection fraction (EF) are shown in the lower panel and EF is plotted against EDV in the upper panel. $S V$ increases in patients with a greater EDV so that $E F$ is normal or increased in all patients except patient 14, who was taking propranolol. Solid symbols are used for patients with a raised jugular venous pressure. failure (Table 4). It contracted well so that measurements of fractional fibre shortening $(\% \Delta S$ and EF) were normal (Fig. 4). The measurements were slightly decreased in the elderly patient with chronic chest disease (Case 3) and in Case 14 (who was taking propranolol). In 3 patients cardiac output was conspicuously increased. Two of these patients had fluid overload and the signs of cardiac failure (Table 4 and Fig. 5). The other patient (Case 13) was not in cardiac failure at the time of study but had a large hypertrophied heart from previous hypertension and recurrent episodes of fluid overload and cardiac failure. He also had an arteriovenous shunt at the time of study.
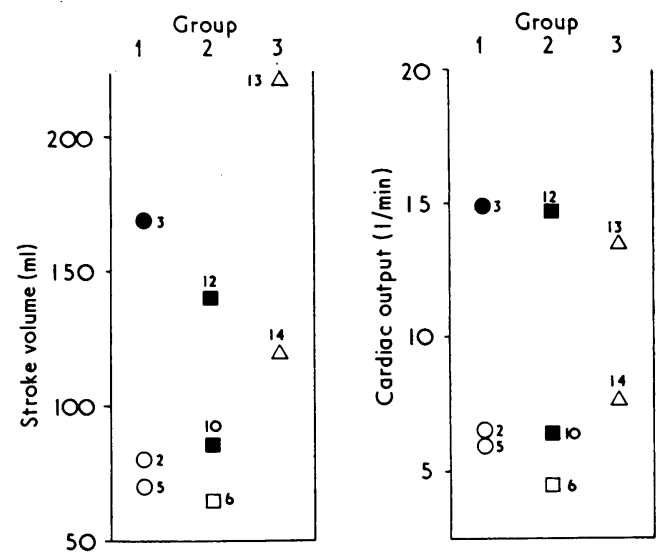

FIG. 5 Stroke volume and cardiac output in the 3 groups. Stroke volume and cardiac output are greatly increased in Cases 3 and 12 (who had severe fluid overload and an increased jugular venous pressure) and in Case 13, who had severe fluid overload and previous hypertension but normal jugular venous pressure at the time of study following haemodialysis.

TABLE 4 Echocardiographic data in relation to clinical right heart failure

\begin{tabular}{|c|c|c|c|c|c|c|c|c|}
\hline $\begin{array}{l}\text { Case } \\
\text { No. }\end{array}$ & $\begin{array}{l}D d \\
(\mathrm{~cm})\end{array}$ & $\begin{array}{l}D s \\
(\mathrm{~cm})\end{array}$ & $\% \Delta S$ & $E F(\%)$ & $\begin{array}{l}\text { Echo } S V \\
(\mathrm{ml})\end{array}$ & $\begin{array}{l}C O \\
(l / \min )\end{array}$ & $\begin{array}{l}\text { Mean Vcf } \\
\text { (circ/s) }\end{array}$ & $\begin{array}{l}\text { Mitral DCR } \\
(\mathrm{mm} / \mathrm{s})\end{array}$ \\
\hline \multicolumn{9}{|c|}{ Group $A$ : normal fVP } \\
\hline $\begin{array}{l}2 \\
5 \\
6 \\
7\end{array}$ & $\begin{array}{l}4 \cdot 8 \\
4 \cdot 7 \\
4 \cdot 4 \\
-\end{array}$ & $\begin{array}{l}3 \cdot 2 \\
3 \cdot 3 \\
2 \cdot 7 \\
-\end{array}$ & $\begin{array}{l}34 \\
31 \\
39 \\
-\end{array}$ & $\begin{array}{l}71 \\
67 \\
76 \\
-\end{array}$ & $\begin{array}{l}80 \\
71 \\
65 \\
-\end{array}$ & $\begin{array}{l}6 \cdot 4 \\
6 \cdot 2 \\
4 \cdot 4 \\
-\end{array}$ & $\begin{array}{l}1 \cdot 13 \\
1 \cdot 17 \\
1 \cdot 38 \\
-\end{array}$ & $\begin{array}{l}56 \\
80 \\
61 \\
78\end{array}$ \\
\hline \multicolumn{9}{|c|}{ Group $B$ : increased $\mathcal{F V P}$} \\
\hline $\begin{array}{r}3 \\
10 \\
12\end{array}$ & $\begin{array}{l}6 \cdot 5 \\
5 \cdot 0 \\
5 \cdot 8\end{array}$ & $\begin{array}{l}4 \cdot 8 \\
3 \cdot 4 \\
3 \cdot 8\end{array}$ & $\begin{array}{l}27 \\
32 \\
35\end{array}$ & $\begin{array}{l}61 \\
69 \\
72\end{array}$ & $\begin{array}{r}168 \\
86 \\
140\end{array}$ & $\begin{array}{r}14 \cdot 9 \\
6 \cdot 3 \\
14 \cdot 7\end{array}$ & $\begin{array}{l}1.08 \\
1.05 \\
1.41\end{array}$ & $\begin{array}{r}160 \\
80 \\
130\end{array}$ \\
\hline $\begin{array}{l}\text { Normal value * } \\
\pm \mathrm{SD}\end{array}$ & $4 \cdot 40 \pm 0 \cdot 28$ & $2 \cdot 83 \pm 0.26$ & $35 \cdot 5 \pm 3 \cdot 9$ & $73 \pm 5$ & $63 \pm 12$ & $4 \cdot 3 \pm 0 \cdot 8$ & $1.22 \pm 0.13$ & - \\
\hline
\end{tabular}

See text for details of abbreviations and indices.

$\star$ McDonald, Feigenbaum, and Chang (1972). 
The velocity measurements mean Vcf and mean Vpwm were normal except in Case 14, who was taking propranolol (Table 3, Fig. 6).

The mitral diastolic closure rate was normal or increased. It was increased in patients who had a large stroke volume $(r=0.97, P<0.01)$, except in Case 13, who had a relatively low mitral diastolic closure rate (Fig. 7). This may reflect an abnormality of ventricular compliance in this patient and may explain his recurrent episodes of cardiac failure. Mitral diastolic closure rate was also related to rapid filling period (O-H time): patients with a large stroke volume and an increased mitral diastolic closure rate had rapid ventricular filling in early diastole and a short $\mathrm{O}-\mathrm{H}$ time $(\mathrm{r}=-0.80, \mathrm{P}>0.05)$.

\section{Serial study}

Case 12 presented with severe uraemia which had not been treated. He was ill with hypertension, anaemia, fluid overload, tachycardia, and a raised jugular venous pressure. He had a large stroke volume and cardiac output with a large left ventricular end-diastolic volume. The left ventricle contracted very well ( $\% \Delta S 35 \%$; mean Vcf 1.41 circ/s; ejection fraction $72 \%$ ) (Fig. 8).

Three hours after peritoneal dialysis arterial blood pressure was unchanged. He had lost $4 \mathrm{~kg}$ in weight and the left ventricular end-diastolic volume, left atrial volume, and aortic root diameter were smaller. Stroke volume decreased and cardiac output was maintained by reflex tachycardia. He was slightly volume-depleted. There was also a change in measurements of left ventricular function
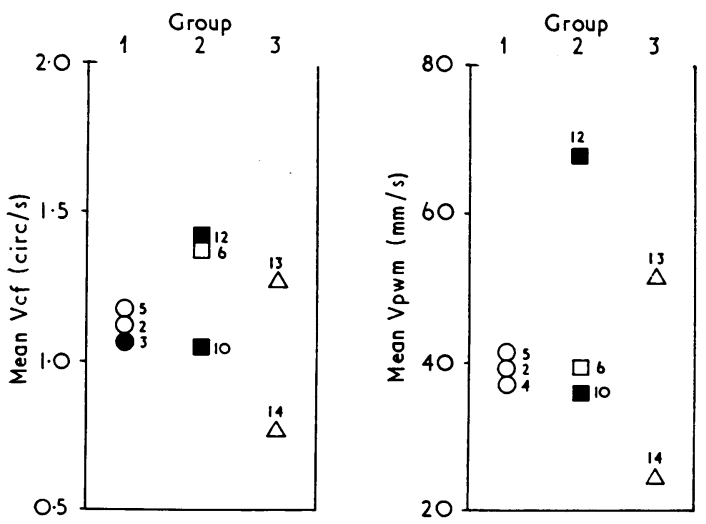

FIG. 6 Velocity measurements of left ventricular function. Mean Vcf and Vpwm are normal or increased in all patients except Case 14, who was taking propranolol. with a small decrease in mean Vcf, mean Vpwm, and ejection fraction, as a result of the operation Starling's law. The systolic time intervals reflected these changes: PEP increased, $\triangle$ LVET decreased, and the PEP/LVET ratio was higher, after dialysis (Fig. 8).

\section{Discussion}

There are several studies of circulatory dynamics in renal failure (Agrest and Finkielman, 1967; Gibson, 1966; Del Greco et al., 1969; Neff et al., 1971) and different mechanisms have been suggested to explain the abnormal findings. There is an increased volume and pressure load on the left ventricle, there may be pericardial disease, and there may be additional coronary artery disease (Lewin and Trautman, 1971; Popowniak, Nakamoto, and Shaldon, 1975). In addition, myocardial performance may be altered by electrolyte disturbances or by a specific toxic substance with myocardial depressant action. Animal experiments in guinea-pigs, frogs, and rabbits (Raab, 1944) and in isolated rat heart preparations provide evidence for a cardiac depressant effect of uraemic serum (Prosser and Parsons, 1975; Hennemann et al., 1975). Dietary factors may be important (Bailey, Hampers, and Merrill, 1967) and Gotloib and Servadio (1975) have reported a patient in whom chronic haemodialysis was complicated by beriberi heart failure. Pathological changes are frequent

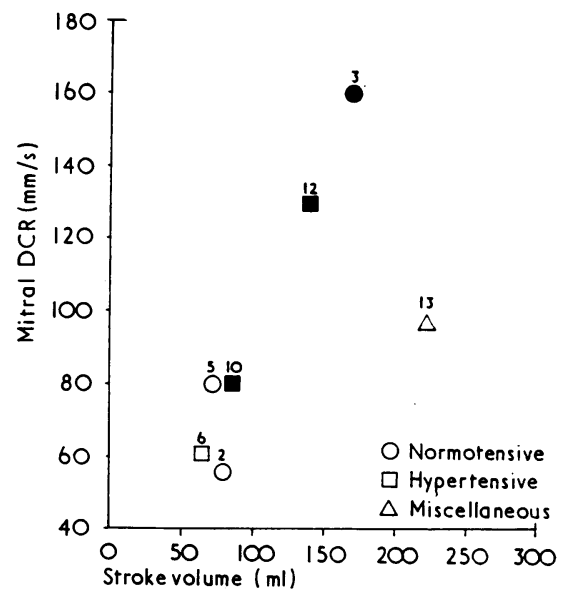

FIG. 7 Linear relation between stroke volume (SV) and mitral diastolic closure rate (DCR) $(r=0.97$, $P<0.01)$. In Case 13 the DCR is not increased despite the high $S V$. 
in the myocardium of patients with the uraemic syndrome (Langendorf and Pirani, 1947). However, cardiac output and cardiac performance are enhanced in some animals with acute and short-term chronic renal failure (Knowlan, Piatnek, and Olson, 1961; Penpargkul and Scheuer, 1972).

There are no detailed studies of left ventricular function in patients with uraemia. Newmark and Kohn (1974) showed a change in STI measurements after renal transplantation and they interpreted this
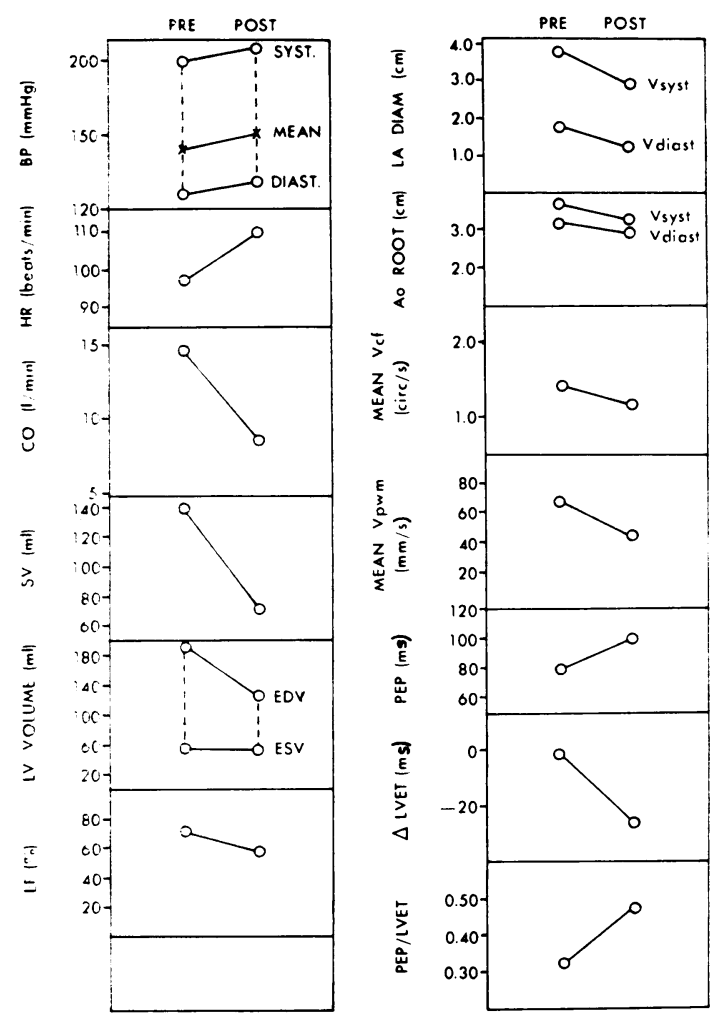

FIG. 8 Serial study in Case 12 before (pre) and 3 hours after (post) peritoneal dialysis. There is little change in arterial blood pressure (BP). All measurements of cardiac volume are smaller after dialysis ( $L V$ end-diastolic volume, left atrial diameter, and the aortic root diameter). Stroke volume (SV) and the velocity measurements of $L V$ function (mean Vcf and Vpwm) decrease by operation of the Starling effect. Cardiac output (CO) falls and there is reflex tachycardia. These changes are reflected in the systolic time intervals: there is an increase in PEP, a decrease in LVET, and an increase in the PEP/ LVET ratio after dialysis. $V$ syst $=$ ventricular systole; $V$ diast $=$ ventricular diastole. as showing an improvement in myocardial performance. Bornstein et al. (1975) studied a group of patients before and immediately after dialysis using STI and showed that PEP increased while LVET and $\triangle$ LVET decreased: this was attributed to a Starling effect, with or without a change in myocardial contractility. The serial study on our patient confirms their findings. Other published reports suggest the syndrome of uraemic cardiomyopathy, but on the basis of clinical findings alone without left ventricular function studies (Ianhez, Lowen, and Sabbaga, 1975).

The present study provides no evidence for the existence of a specific uraemic cardiomyopathy. On the contrary, systolic function of the left ventricle is normal, even in patients who are severely uraemic, hypertensive, fluid-overloaded, and anaemic, clinically ill and with the physical signs of cardiac failure. The heart is enlarged but myocardial performance is normal as measured by $\% \Delta S$, ejection fraction, and mean Vcf so that stroke volume and cardiac output are increased as a result of operation of the Starling mechanism. It is possible that more sensitive techniques for assessing left ventricular performance may show that the response to the loading conditions is normal but suboptimal in chronic renal failure; we have not studied the patients during and after exercise since many of them were very ill. None the less, overall left ventricular function is normal at rest and it seems that a 'myocardial factor' is not important clinically in the pathogenesis of cardiac failure in uraemia unless additional cardiac disease (e.g. coronary artery disease) is present.

It should be noted that STI measurements must be interpreted carefully in patients who have abnormal loading conditions (Karnegis and Wang, 1961; Talley, Meyer, and McNay, 1971). Despite normal echocardiographic measurements, PEP is prolonged in some of our patients and the PEP/ LVET ratio is increased. This does not necessarily indicate an alteration in myocardial contractility since preload and afterload are abnormal; $\triangle \mathrm{PEP}$ is related to arterial diastolic pressure and to $\Delta \mathrm{Q}-\mathrm{Ml}$, supporting this view. A similar discrepancy has been seen in patients with chronic obstructive pulmonary disease, who have abnormal STI measurements but normal LV systolic function as measured by more direct techniques (Unger et al., 1975).

Left ventricular compliance is normal in early diastole, and the mitral diastolic closure rate increases appropriately in patients who are fluidoverloaded with a large stroke volume. The patient studied after renal transplantation (Case 13) had a disproportionately slow mitral diastolic closure rate despite a large stroke volume. This 
suggests that he had abnormal ventricular compliance and may explain recurrent episodes of cardiac failure for which he was treated with digitalis. The cause of this altered compliance is uncertain. There was a long history of fluid overload and hypertension (though these were controlled by drugs at the time of study). The patient died subsequently and necropsy was performed. The left ventricle was greatly hypertrophied and dilated; the severe left ventricular hypertrophy may explain the decreased ventricular compliance (Grossman et al., 1974). Systolic function had been adequate despite the abnormal loading conditions.

In summary, left ventricular performance was normal both in systole and diastole in all but 2 of our patients. One (Case 14) had a slight decrease in systolic left ventricular function and this was thought to be the effect of propranolol in a patient dependent on sympathetic compensatory mechanisms to maintain normal haemodynamics. The other (Case 13) had good systolic function but altered diastolic compliance of the left ventricle, probably caused by severe left ventricular hypertrophy. Several other patients were extremely ill with uraemia, hypertension, and fluid overload at the time of study, but in all of these left ventricular function was good. It seems that uraemia itself is not associated with myocardial dysfunction.

\section{References}

Agrest, A., and Finkielman, S. (1967). Hemodynamics in acute renal failure. American fournal of Cardiology, 19, 213.

Bailey, G. L., Hampers, C. L., and Merrill, J. P. (1967). Reversible cardiomyopathy in uremia. Transactions of the American Society of Artifical Internal Organs, 13, 263.

Bornstein, A., Zambrano, S. S., Morrison, R. S., and Spodick, D. H. (1975). Cardiac effects of hemodialysis: noninvasive monitoring by systolic time intervals. American fournal of the Medical Sciences, 269, 189.

Del Greco, F., Simon, N. M., Roguska, J., and Walker, C. (1969). Hemodynamic studies in chronic uremia. Circulation, 40, 87.

Feigenbaum, H. (1962). Echocardiography. Lea and Febiger, Philadelphia.

Fortuin, N. J., Hood, W. P., Jr., and Craige, E. (1972). Evaluation of left ventricular function by echocardiography. Circulation, 46, 26.

Garrard, C. L., Jr., Weissler, A. M., and Dodge, H. T. (1970), The relationship of alterations in systolic time intervals to ejection fraction in patients with cardiac disease. Circulation, 42, 455.

Gibson, D. G. (1966). Haemodynamic factors in the development of acute pulmonary oedema in renal failure. Lancet, $2,1217$.

Gotloib, L., and Servadio, C. (1975). A possible case of beriberi heart failure in a chronic haemodialyzed patient. Nephron, 14, 293.

Grossman, W., McLaurin, L. P., Moss, S. P., Stefadouros, M., and Young, D. T. (1974). Wall thickness and diastolic properties of the left ventricle. Circulation, 49, 129.
Gueron, M., Berlyne, G. M., Nord, E., and Ben Ari, J. (1975). The case against the existence of a specific uremic myocardiopathy. Nephron, 15, 2.

Hennemann, H., Arnold, H., Hevendehl, G., Heidland, A., and Kissling (1975). Uraemic cardiomyopathy. Abstract 555, VIth International Congress of Nephrology, Florence, June 8-12.

Ianhez, L. E., Lowen, J., and Sabbaga, E. (1975). Uremic myocardiopathy. Nephron, 15, 17.

Karliner, J. S., Gault, J. H., Eckberg, D., Mullins, C. B., and Ross, J., Jr. (1971). Mean velocity of fiber shortening. A simplified measure of left ventricular myocardial contractility. Circulation, 44, 323.

Karnegis, J. N., and Wang, Y. (1961). The phonocardiographic Q-1 interval in patients with ventricular septal defect and left-to-right shunt. Clinical Research, 9, 141.

Knowlan, D. M., Piatnek, D. A., and Olson, R. E. (1961). Myocardial metabolism and cardiac output in acute uremia. Clinical Research, 9, 141.

Kumar, S., and Spodick, D. H. (1970). Study of the mechanical events of the left ventricle by atraumatic techniques: comparison of methods of measurement and their significance. American Heart fournal, 80, 401.

Langendorf, R., and Pirani, C. L. (1947). The heart in uremia. An electrocardiographic and pathologic study. American Heart Fournal, 33, 282.

Lewin, K., and Trautman, L. (1971). Ischaemic myocardial damage in chronic renal failure. British Medical fournal, 4, 151 .

Lewis, B. S., Armstrong, T. G., Everson, R. C., and Gotsman, M. S. (1973). Predictive value of the systolic time intervals in primary myocardial disease. Chest, 64, 431.

Linhart, J. W., Mintz, G. S., Segal, B. L., Kawai, N., and Kotler, M. N. (1975). Left ventricular volume measurement by echocardiography: fact or fiction? American fournal of Cardiology, 36, 114.

Manolas, J., Rutishauser, W., Wirz, P., and Arbenz, U. (1975). Time relation between apex cardiogram and left ventricular events using simultaneous high-fidelity tracings in man. British Heart fournal, 37, 1263.

McDonald, I. G. (1974). Assessment of myocardial function by echocardiography. Advances in Cardiology, 12, 221.

McDonald, I. G., Feigenbaum, H., and Chang, S. (1972). Analysis of left ventricular wall motion by reflected ultrasound. Application to assessment of myocardial function. Circulation, 46, 14.

Neff, M. S., Kim, K. E., Persoff, M., Onesti, G., and Swartz, C. (1971). Hemodynamics of uremic anemia. Circulation, 43, 876.

Newmark, K. J., and Kohn, P. (1974). Myocardial functional improvement in the post renal transplantation state assessed by systolic time intervals (abstract). Kidney International, 6, 79A.

Penpargkul, S., and Scheuer, J. (1972). Effect of uraemia upon the performance of the rat heart. Cardiovascular Research, 6, 702 .

Popowniak, K. L., Nakamoto, S., and Shaldon, W. (1975). Cinecardioangiography, a useful study to determine cardiac status in patients with chronic renal failure. Abstract 624, VIth International Congress of Nephrology, Florence, June 8-12.

Popp, R. L., Filly, K., Brown, O. R., and Harrison, D. C. (1975). Effect of transducer placement on echocardiographic measurement of left ventricular dimensions. American fournal of Cardiology, 35, 537.

Prewitt, T., Gibson, D., Brown, D., and Sutton, G. (1975). The rapid filling wave of the apex cardiogram. Its relation to echocardiographic and cineangiographic measurements of ventricular filling. British Heart fournal, 37, 1256. 
Prosser, D., and Parsons, V. (1975). The case for a specific uremic myocardiopathy. Nephron, 15, 4.

Quinones, M. A., Gaasch, W. H., Cole, J. S., and Alexander, J. K. (1975). Echocardiographic determination of left ventricular stress-velocity relations in man. Circulation, $51,689$.

Quinones, M. A., Gaasch, W. H., Waisser, B., and Alexander, J. K. (1974). Reduction in the rate of diastolic descent of the mitral valve echogram in patients with altered left ventricular diastolic pressure-volume relations. Circulation, 49, 246.

Raab, W. (1944). Cardiotoxic substances in the blood and heart muscle in uremia. Fournal of Laboratory and Clinical Medicine, 29, 715.

Ross, J., Jr., Covell, J. W., and Mahler, F. (1974). Contractile responses of the left ventricle to acute and chronic stress. European fournal of Cardiology, 1, 325.

Shah, P. M., and Slodki, S. J. (1964). The Q-II interval. A study of the second heart sound in normal adults and in systemic hypertension. Circulation, 29, 551.

Skloven, D., Peterson, K., Uther, J., and Ross, J., Jr. (1972). Comparison of isovolumic and ejection phase indices of contractility in man (abstract). Circulation, 46, Suppl. 2, 45.
Talley, R. C., Meyer, J. F., and McNay, J. L. (1971). Evaluation of the pre-ejection period as an estimate of myocardial contractility in dogs. American fournal of Cardiology, 27, 384.

Unger, K., Shaw, D., Karliner, J. S., Crawford, M. O'Rourke, R. A., and Moser, K. M. (1975). Evaluation of left ventricular performance in acutely ill patients with chronic obstructive lung disease. Chest, 68, 135.

Weissler, A. M. (1974). Non-invasive Cardiology. Grune and Stratton, New York.

Weissler, A. M., Harris, W. S., and Schoenfeld, C. D. (1968) Systolic time intervals in heart failure in man. Circulation, 37, 149.

Weissler, A. M., Peeler, R. G., and Roehll, W. H., Jr. (1961). Relationships between left ventricular ejection time, stroke volume, and heart rate in normal individuals and patients with cardiovascular disease. American Heart fournal, $62,367$.

Requests for reprints to Dr. B. S. Lewis, Cardiac Unit, Hadassah Hospital, P.O. Box 499, Jerusalem, Israel. 